\title{
Research on the Role of High-tech Industry in Jilin Province's Regional Economic Growth
}

\author{
Jie Yao \\ School of Economy and Management \\ Northeast Dianli University \\ Jilin City, China \\ leeyooab@163.com
}

\author{
Jin-shan Li \\ School of Economy and Management \\ Northeast Dianli University \\ Jilin City, China \\ 1805930026@qq.com
}

\begin{abstract}
This paper first analyzed the overall status of hightech industry in Jilin province from the following four aspects, including the development scale of high-tech enterprises, the changing tendency of main economic benefit indexes, the ability of easing employment pressure and the innovative ability. On this basis, through the statistical analysis of historical data, this paper calculated the contribution rate of high-tech industry in Jilin Province regional economic growth, and made in-deep analysis of the important roles that high-tech industry has played in Jilin Province's regional economic growth. Finally, this paper gave conclusions and put forward suggestions to promote the development of the High-tech Industry of Jilin Province.
\end{abstract}

Keywords-high-tech industry; regional economic growth; contribution rate of industry; industrial added value

\section{INTRODUCTION AND LITERATURE REVIEW}

In recent years, Jilin province's high-tech industry has entered a period of rapid development. Until 2013, there have been a total of 394 high-tech enterprises in Jilin Province with about 151519 practitioners annually. The main business income has been 143.13 billion yuan which is $25.70 \%$ more than that of last year. The profit has grown to be 11.53 billion yuan, $23.45 \%$ more than that of last year. The total amount of profit and tax has reached 18.02 billion yuan, 28.55\% more than that of previous year. The export of high-tech industry has been 1.97 billion yuan, accounting for $1.38 \%$ of the main business income.

So far, many scholars have done some research work on the problems related with the development of high-tech industry, and the results are mainly focused on the following aspects.

Some scholars have done some research work on the competitiveness and efficiency of high-tech industry, for example, L. Jun-ling (2016) has done empirical study on the efficiency of China's high-tech industry based on PCA and three-stage DEA model [1]. C. Hong-chuan (2010) set up the evaluation index system of the competitiveness of high-tech industry, and evaluated the competitiveness of high-tech industry by using data mining methods[2]. L. Tuo-chen (2010) analyzed the key indicators of China's high-tech industry in the past ten years from the following six aspects respectively, including the scale and added value of high-tech industry, the direct wealth created by high-tech industry, the labor productivity of high-tech industry, the import and export of high-tech industry, and the technological capability of hightech industry[3].

Some scholars have carried on a large amount of research on the development of national or provincial high-tech industry. For example, basing on the panel data of Jiangxi Province's high-tech industry and economic development from 2001 to 2014, D. Zhi-min and Z. Wan-teng (2016) made an empirical test on the spillover effect of Jiangxi Province's high-tech industry by using Feder's two-department model [4] Y. Xin (2015) analyzed the development of Jiangsu province's high-tech industry[5]. W. Xiao-ting and W. Fan (2014) analyzed the status quo of Jilin province's high-tech industry by using qualitative analysis method [6].

And some scholars have done some research work from the perspective of supporting the development of high-tech industry. For example, H. Yi-lin (2015) carried on the comprehensive analysis on the new content of tax preferential policies after the implementation of the new tax law of enterprise income and put forward some suggestions to solve the problems existing in the preferential policies [7]. X. Na (2015) considered the preferential tax system of high-tech industry as the main point and put forward some countermeasures to guarantee the continuous development of the related preferential tax policy for high-tech industry [8].

A few scholars has made some research work on the roles that high-tech industry has played in promoting the economic growth, for example, Z. Yong-gao (2013) has done empirical analysis on the effect that high-tech industry cluster has on the economic growth of Guangdong Province by using factor analysis and regression analysis method [9].

From the literature review above, the research work many scholars have done mainly focus on the status quo of high-tech industry, the competitiveness evaluation of high-tech industry and the policies supporting the development of high-tech industry. But little quantitative research work has been done on the roles that high-tech industry has played in promoting the regional economic growth of Jilin Province. Therefore this paper did some research work on it in order to supplement the current research results of this field. 


\section{ThE OVERALL STATUS OF High-TECH INDUSTRY IN JILIN PROVINCE}

\section{A. Development Scale of High-tech Enterprises}

The high-tech enterprises in Jilin province have begun to take shape after years of development. By the end of 2013, there have been a total of 26894 high-tech enterprises in China's five largest high-tech industries, with 394 enterprises in Jilin province, accounting for only $1.47 \%$ of the total, which indicates there is still a certain gap from the national average level. The high-tech enterprises in Jilin province are mainly concentrated in the pharmaceutical manufacturing industry, electronic and communication equipment manufacturing industry, medical equipment and instrument manufacturing industry. There are few enterprises in aerospace manufacturing industry and electronic computer and office equipment manufacturing industry, so the development of these two industries is slow.

\section{B. Changing Tendency of Main Economic Benefit Indexes}

Three indicators are used to evaluate the benefit of hightech industry. They are return on assets, business income, profits and taxes. Jilin Province's high-tech industry has maintained rapid growth tendency in recent years. By analyzing the original data, we can notice that the amount of the main business income, profit, profit and tax, and other indicators have been increasing year after year. The proportion that these three indicators of Jilin Province account for those of the whole nation basically keeps increasing, but there is still great difference compared with the national level. They only occupied fewer shares and reached 1.23\%, 1.59\% and $1.62 \%$ in 2013, showing that the profitability of Jilin Province's hightech industry is still weak.

\section{Ability of Easing Employment Pressure}

During the past ten years, the number of high-tech industry's practitioners in Jilin province has kept increasing with slight fluctuations. The ability of high-tech industry in Jilin Province to alleviate employment pressure can be shown by the ratio of the number of high-tech industry's practitioners to the total of Jilin province, details are in Fig. 1.

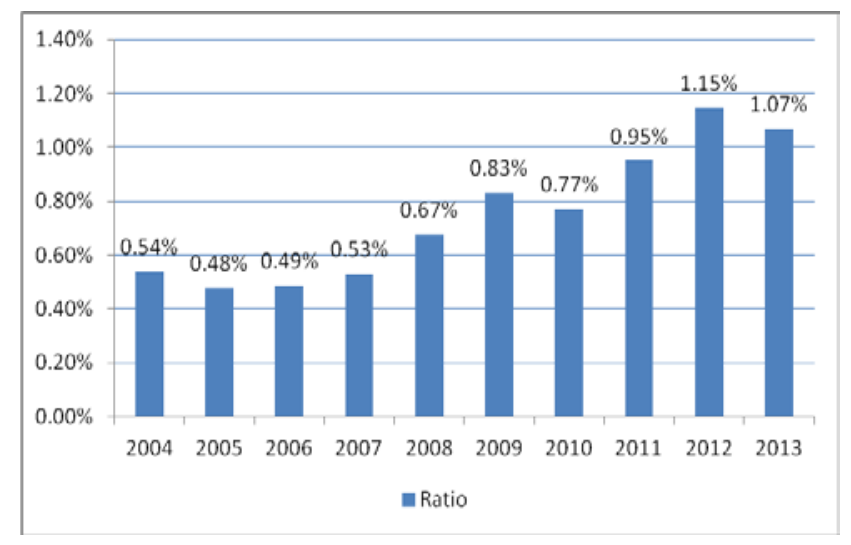

Fig. 1. Ratio of the number of high-tech industry practitioners to the total of Jilin province from 2004 to 2013
Compared with $0.54 \%$ in 2004, the ability of Jilin Province's high-tech industry to ease employment pressure has improved obviously, with the ratio to be $1.07 \%$ in 2013 , but still accounting for only a smaller share of the total of Jilin Province. In addition, by statistical analysis, the number of practitioners in Jilin Province's high-tech industry accounted for only $1.17 \%$ of national total in 2013, indicating that the overall scale of Jilin Province's high-tech industry is still small and its ability to alleviate employment pressure is still low compared with the national level.

\section{Innovative Ability}

In recent years, the innovation capacity of Jilin Province's high-tech Industry has increased sharply. The input of new product development funding continues to grow, and hightech talents continue to be introduced. Therefore, the high tech industry in Jilin Province has shown vigor, and achieved fruitful results.

TABLE I. INCREASING PERCENT OF KEY INDICATORS OF THE TECHNOLOGICAL INNOVATION ACTIVITIES OF JILIN PROVINCE’S HIGH-TECH ENTERPRISES

\begin{tabular}{|l|c|}
\hline \multicolumn{1}{|c|}{ Indicators } & $\begin{array}{c}\text { Increasing Percent } \\
\text { from 2009 to 2013 }\end{array}$ \\
\hline Scientific Research Institutions & $47.17 \%$ \\
\hline Institutional Personnel & $17.93 \%$ \\
\hline Expenditures On New Product Development & $91.54 \%$ \\
\hline New Product Sales Revenue & $128.47 \%$ \\
\hline Number Of Patent Applications & $81.07 \%$ \\
\hline Number Of Invention Patents & $84.19 \%$ \\
\hline
\end{tabular}

As can be seen from the Table 1, Jilin Province has jumped to a new level on the following aspects in 2013 compared with the data of 2009, including the number of scientific research institutions, the number of institutional practitioners, and the expenditures on the new product development. In particular, the expenditures on new product development have been $91.54 \%$ more than that of 2009. There are also some new breakthroughs in output, with new product sales revenue growing by $128.47 \%$, the number of patent applications growing by $81.07 \%$, and the number of owing patents growing by $84.19 \%$.

\section{CONTRIBUTION OF HIGH-TECH INDUSTRY TO JILIN PROVINCE's REGIONAL ECONOMIC GROWTH}

\section{A. Changing Tendency of the Added Value of Jilin Province's High-Tech Industry}

With less resource consumption, less environmental pollution and high economic benefit, high-tech industry has become the development focus of various regions, and will become the main force in future competition. According to the statistical bulletin of national economic and social development of Jilin province from 2009 to 2014, we can get the ratio of the added value of high-tech industry to Jilin 
Province's regional product and the ratio of that to the added value of the whole industry, as shown in Fig. 2.

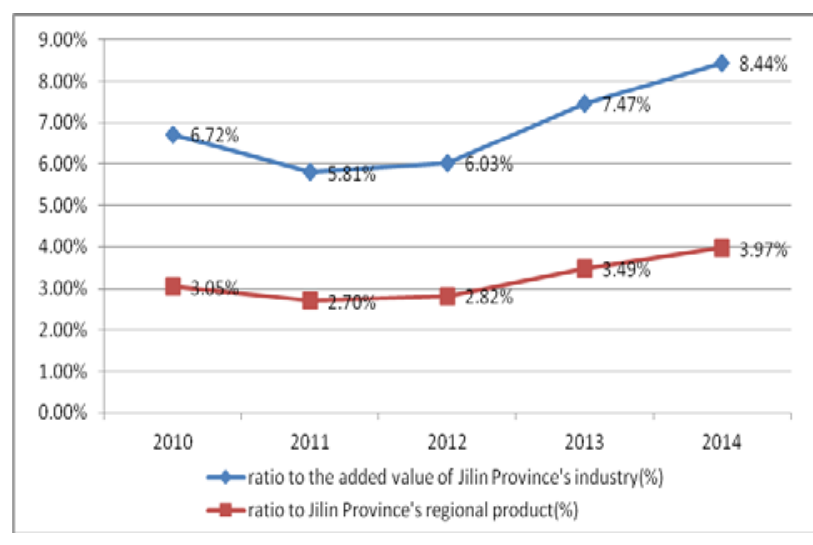

Fig. 2. Ratio of the added value of high-tech industry to Jilin province's regional GDP

It can be seen from Fig. 2 that the ratio of the added value of high-tech industry to Jilin Province's regional product and the ratio of that to the added value of the whole industry declined in 2011 first and then continue to increase year by year. They have been $3.97 \%$ and $3.97 \%$ respectively by the end of 2014. The ratio of the added value of high-tech industry to the added value of the whole industry has been increasing faster than the one to Jilin Province's regional product. To some extent, it has reflected the adjustment of Jilin province's industrial structure.

\section{B. Calculation of the contribution rate of high-tech industry}

to Jilin Province's regional economic growth

In order to measure the contribution of high-tech industry, this paper collected the data of industrial contribution rate from 2010 to 2013 from the statistical yearbook of Jilin Province and calculated the corresponding year's contribution rate of high-tech industry to the economic growth of Jilin Province according to formula 1 . The results are shown in Table 2.

$$
\mathrm{HC}=\mathrm{IC} * \mathrm{RHI}
$$

$$
\mathrm{HC}=\text { contribution rate of high-tech industry }
$$$$
\mathrm{IC}=\text { contribution rate of the whole industry }
$$

$\mathrm{RHI}=$ the ratio of high-tech industry's added value to the whole industry's added value

It can be seen from the data in Table 2 that, Jilin Province's industrial contribution rate has been significantly reduced in 2013, but the ratio of high-tech industry's added value to the added value of the whole industry has been increased significantly compared with the data of 2010. This fully shows that industrial structure of Jilin Province has been continuously adjusted and upgraded. And the contribution rate of Jilin Province's high-tech industry obtained according to formula 1 has fluctuated in the past few years. It has reached $4.12 \%$ in 2013 , exceeding $4.01 \%$ of 2010 . This indicates that the contribution of high-tech industry to the regional economic growth of Jilin Province has also been increasing. With the further development of science and technology, high-tech industry will be more effective in promoting the regional economic growth of Jilin province and will play an important role in deciding the status of Jilin Province in the whole country's economic development.

TABLE II. CONTRIBUTION RATE TO JILIN PROVINCE’S REGIONAL ECONOMIC GROWTH

\begin{tabular}{|c|c|c|c|c|}
\hline \multirow{2}{*}{ Item } & \multicolumn{4}{|c|}{ Year } \\
\cline { 2 - 5 } & 2010 & 2011 & 2012 & 2013 \\
\hline $\begin{array}{c}\text { Contribution rate of } \\
\text { the whole industry }\end{array}$ & $59.60 \%$ & $61.60 \%$ & $54.70 \%$ & $55.10 \%$ \\
\hline $\begin{array}{c}\text { Contribution rate of } \\
\text { high-tech industry }\end{array}$ & $4.01 \%$ & $3.58 \%$ & $3.30 \%$ & $4.12 \%$ \\
\hline
\end{tabular}

\section{CONCLUSION AND SUGGESTIONS}

High-tech industry is the economic field that the whole country and even the whole world are striving to develop. Healthy and vigorous development of high-tech industry will be of great significance in improving the regional GDP of Jilin Province and enhancing the competitiveness of the industry. Through the analysis above, the paper drew the following conclusions.

First, the development scale of high-tech enterprises is still small in Jilin Province. They only accounted for $1.47 \%$ of the national total in 2013. The high-tech enterprises mainly concentrate in the following industries in Jilin province, including manufacture of medicines, manufacture of electronic equipment and communication equipment, manufacture of medical equipments and measuring instrument. There are few enterprises in manufacture of aircrafts and spacecrafts, and manufacture of computers and office equipments. And the development of these two industries is slow. Now Jilin province has reached the leading level in automobile manufacturing industry, microelectronics, chemical industry and new energy development in China.

Second, Although the high-tech industry has maintained rapid growth in recent years in Jilin Province, but there is still great difference compared with the national level. The economic indicators, such as main business income, profits, profits and taxes, account for less than $2 \%$ of the whole country.

Third, although the overall size of the practitioners in the high-tech industry of Jilin Province keeps growing, but there is still a big gap compared with the national level, accounting for about $1 \%$ of the total. In recent ten years, the ability of high-tech industry to ease employment pressure has been improved obviously in Jilin Province, but the practitioners in high-tech industry still account for a small share of the whole Province's.

Fourth, the technological innovation activities of Jilin Province's high-tech enterprises have shown a good momentum of development in recent years. The value of each indicator has improved significantly, but there is still a big gap compared with the national average level, the ratios of each 
indicator to the national total were all less than $1 \%$, so there is still much room for the high-tech industry of Jilin Province to improve.

Fifth, the industrial contribution rate of Jilin province is continuously decreasing, while the ratio of the high-tech industry's added value to that of the industry keeps increasing in recent years, which fully indicates that the industrial structure of Jilin province has been constantly adjusted and optimized. The contribution rate of Jilin province's high-tech industry has reached $4.12 \%$ in 2013 , which is more than $4.01 \%$ of 2010 . This indicates that the contribution of hightech industry to Jilin province's regional economic growth is also increasing.

Through the analysis above, Jilin province should vigorously develop high-tech industry, which will help to promote regional economic growth, alleviate employment pressure, and improve the enterprise's technological innovation ability. Therefore, attracting high-tech talents, encouraging scientific research work and innovations are all the most effective ways for Jilin Province to develop high-tech industry, promote the growth of regional economy and keep the vitality of regional economy.

\section{ACKNOWLEDGMENT}

This research was financially supported by the base project of Social Science Foundation of Jilin Province "Empirical study on the influence factors and efficiency measurement of wind energy development and utilization in Jilin Province" (Grant NO. 2016JD58) and the 12th Five-Year planning project of Jilin Province’s Education Department “Empirical Study on the Measurement and Evaluation of the Technical Efficiency of Jilin Province's High-tech Industry” (Grant NO.2015-171).

\section{REFERENCES}

[1] L. Jun-ling, "Research on efficiency of China's high-tech industry -- an empirical analysis based on PCA and three stage DEA model,” Journal of Liaoning Technical University (SOCIAL SCIENCE EDITION), pp. 25-32, January 2016.(In Chinese)

[2] C. Hong-chuan, "Empirical Study on the evaluation of competitiveness of high-tech industry,” Soft Science, pp. 21-23,29 , August 2010.(In Chinese)

[3] L. Tuo-chen, "Analysis on the main indicators of the competitiveness of China's high-tech industry,” Fortune World, pp. 28-33, January 2010.(In Chinese)

[4] D. Zhi-min, Z. Wan-teng, "Feder model analysis on the spillover effect of High-tech industry -- Taking Jiangxi Province as an example,” East China Economic Management, pp. 26-30, January 2016.(In Chinese)

[5] Y. Xin, “Analysis on the development of High-tech industry in Jiangsu province,” Wireless Internet Technology, pp. 63-64, November 2015.(In Chinese)

[6] W. Xiao-ting, W. Fan, "The status quo of the high-tech industry in Jilin province,” Market Modernization, pp. 119, February 2014.(In Chinese)

[7] H. Yi-lin, Z. Lu and Z. Bo, "Analysis on tax policy of high-tech industry in 2015,” China Market, vol. 52, 2015, pp. 88, 96.(In Chinese)

[8] X. Na, "The perfect measures of tax preference system of China's hightech industry,” China Market, vol. 51, 2015, pp. 190-191.(In Chinese)

[9] Z. Yong-gao, "Roles of high-tech industry cluster in promoting regional economic growth -- Taking Guangdong Province as an example," Hangzhou: Zhejiang University of Finance and Economics, 2013.(In Chinese) 